\title{
Sustainability of the Economy of Organizations in the Modern Economic Era
}

\author{
S. Yu. Ilyin ${ }^{1, *}$, N. V. Gavrikova², Y. V. Danilkina ${ }^{2}$, T. S. Salnikova², A. O. \\ Iakovleva $^{2}$
}

\author{
${ }^{1}$ Financial University under the Government of the Russian Federation, Moscow, Russian Federation \\ ${ }^{2}$ MIREA - Russian Technological University, Moscow, Russian Federation \\ *Corresponding author.Email: i.sergey777@gmail.com
}

\begin{abstract}
The prepared article is devoted to the author's conceptual approach to the creation of a toolkit, consisting of methods for a comprehensive assessment of the sustainability of the economy of organizations on the basis of static and dynamic dependencies, expressed by its general (resulting) and partial (factor) indicators that are with each other in economicstatistical and economic-mathematical systemic relationships. The final reference point (the goal of the study) is aimed at building an integral structure of the resulting and factor static and dynamic indicators of the stability of the economy of modern organizations for an objective analysis that allows them to identify the reserves necessary for its maximum reliability. Intermediate benchmarks (research tasks) consist in clarifying the structure of their activities, grouping factor indicators of economic stability under it and building causal relationships between them and the resulting indicators. The research methods were chain substitutions and mathematical analysis as suitable ways to combine strategic and tactical actions of organizations to optimize static and dynamic resultant and factor indicators of the stability of their economy. The static indicators include efficiency and cost, and dynamic indicators - the change in the result and costs under the influence of efficiency and cost. Both groups of indicators are adapted to the current economic mechanism, which is characterized by a combination of operational and non-operational (long-term investment and short-term investment) activities, which fully corresponds to the traditional understanding of the patterns of functioning of the economy of organizations and does not conflict with current economic realities. The study will be useful to heads and specialists of organizations, educators and scientists, students of economic directions.
\end{abstract}

Keywords: economy of organizations, static and dynamic indicators of the stability.

\section{INTRODUCTION}

For mankind of the current period of time, the diversification of economic activities of organizations is typical, due to increased competition among them in market segments and a regular struggle to gain a business reputation and attract the attention of potential clients and business partners. Following this phenomenon, they engage in both primary (main) and secondary (other) activities, attempting to hypertrophy available capital, allowing them to expand reproduction and achieve regular growth in living and materialized productivity, which has a direct impact on production and sales turnover, as well as net profit directed for personal consumption and accumulation, that is, investing activities in various economic and social programs of their development. To do so, they'll need to objectively assess the indicators of their activities in statics and dynamics, using a toolkit that includes methods for calculating indicators of organizational stability under modern-day conditions, and the author's research on the subject is devoted to the relevant issues.

The goal of this research is to develop methods for determining complex resulting indicators of the economy's long-term viability for organizations that conduct activities in an environment with multidisciplinary economic processes (business processes) that have systemic concordance with factor indicators affecting their values, in order to identify reserves and ensure maximum reliability. It should be achieved by solving research problems, which include:

1. Clarification of the structure of the activities of organizations that correspond to the current 
economic mechanism, formed on the basis of the prevailing market conditions.

2. Grouping of static and dynamic indicators of the result and costs, according to the market specifics of the activities of organizations doing business under multifactorial economic conditions.

3. Construction of causal relationships between factorial and resulting static and dynamic indicators of the sustainability of the economy of organizations, based on the evolution of the economic system.

To solve the tasks we have set for ourselves, we will choose the most appropriate research methods and approaches, allowing us to obtain complete and trustworthy information about the indicators of organizational economic sustainability and conduct qualitative analysis.

\section{MATERIALS AND METHODS}

The sources of information for assessing the sustainability of the economy of organizations were scientific works published by specialists whose professional interests are related to the activities of legal entities carrying out it in the current economic conditions. In the process of studying general methodological provisions disclosed in the publications of E.G. Andrianova [1], A.S. Bekasova [3], M.A. Petrosyan [8], A.V. Samusenko [9], A.A. Yanyushkina [12], compiled the general structure of the activities of modern organizations, and the study of particular provisions from the works, the authors of which are B.G. Badmaev [2], N.S. Zinchik [4], Yu.N. Kulakova [5], K.S. Levchuk [6], D.Kh. Oleinik [7], N.N. Sokolov [10], A.N. Chesalin [11], we formalize methods that reflect the sustainability of their economy.

The formalization of indicators of the sustainability of the economy of organizations will be carried out through research methods based on chain substitutions and mathematical analysis. Taken together, they ensure the factor's organic nature and the parameters that result, allowing researchers to see how the presented structure of organizational economic stability is balanced by individual elements and, as a result, how reliable its indicators are in static and dynamic time intervals, and how they correspond to management's strategic and tactical decisions.

Using such tools with combined types of settlement relationships, organizations will promptly receive complete and accurate information about the general and private sustainability of the organizations' economy, regulate the correlation between them and optimize the result and costs of activities, ranking activities according to the values obtained and implementing them, according to the priority resulting from the conjunctural significance.

\section{RESULTS AND DISCUSSION}

As previously indicated, the structure of static and dynamic indicators of organizational economic stability is dictated by the particular of their activities, which are marked by a wide variety of major (operational) and other (long-term and short-term investment) business processes. Therefore, organizations, along with operating income (revenue from sales of products) and operating expenses (costs of products sold), calculate investment income (net discounted income (with capital investments), capitalized income (with financial investments)) and investment expenses (capital investments, initial cash deposits). Because these two groups of indicators form the profit they receive (the main source of financing the activities of all legal entities) in the modern era of the functioning of organizations due to commodity-money relations, they should, in the author's opinion, be included in the methods of its assessment.

In a static period of time, they should be used to calculate rationality (efficiency (profitability and profitability) and cost (expenditure on income and profit)) activities of organizations, and in the dynamic period - changes in the result (income and profit) and costs (income and profit expenses). This combination completely unites tactics with the strategy of organizations striving to have solid leadership positions in market segments and speaks of the continuity and stability of reproduction.

Adding up incomes and expenses in turn and then finding between them a direct and an indirect relationship, we obtain integral static indicators of the stability of the economy of organizations in the form of the effectiveness and cost of their activities (formulas (1), (2), (3), (4)):

\section{$R T_{\text {eosp }(d)}=$ $\frac{D_{o d}+D_{\text {did }}+D_{k i d}}{R_{\text {od }}+R_{\text {did }}+R_{\text {kid }}}$}

where RT eosp (d) - direct integral static stability of the economy of organizations in terms of income;

$\mathrm{D}_{\text {od }}$ - income from operating activities, rubles;

$\mathrm{D}_{\mathrm{did}}$ - income from long-term investment activities, rubles;

$\mathrm{D}_{\text {kid }}$ - income from short-term investment activities, rubles;

$\mathrm{R}_{\text {od }}$ - expenses from operating activities, rubles;

$\mathrm{R}_{\text {did }}$ - expenses from long-term investment activities, rubles;

$\mathrm{R}_{\text {kid }}$ - expenses from short-term investment activities, rubles; 


$$
\begin{gathered}
\mathrm{RT}_{\text {eosp }(p)}= \\
\frac{\left(D_{o d}+D_{d i d}+D_{k i d}\right)-\left(R_{o d}+D_{d i d}+D_{k i d}\right)}{R_{o d}+R_{d i d}+R_{k i d}}
\end{gathered}
$$

where RT eosp (p) - direct integral static stability of the economy of organizations in terms of profit;

$\mathrm{D}_{\text {od }}$ - income from operating activities, rubles;

$\mathrm{D}_{\text {did }}$ - income from long-term investment activities, rubles;

D kid - income from short-term investment activities, rubles;

$\mathrm{R}_{\text {od }}$ - expenses from operating activities, rubles;

$\mathrm{R}_{\text {did }}$ - expenses from long-term investment activities, rubles;

$\mathrm{R}_{\text {kid }}$ - expenses from short-term investment activities, rubles;

$\mathrm{ZT}_{\text {eosk (d) }}=$

$\frac{R_{o d}+R_{\text {did }}+R_{\text {kid }}}{D_{\text {od }}+D_{\text {did }}+D_{\text {kid }}}$,

where $\mathrm{ZT}$ eosk (d) is the indirect integral static stability of the economy of organizations in terms of income;

$\mathrm{R}_{\text {od }}$ - expenses from operating activities, rubles;

$\mathrm{R}_{\text {did }}$ - expenses from long-term investment activities, rubles;

$\mathrm{R}_{\text {kid }}$ - expenses from short-term investment activities, rubles;

$\mathrm{D}_{\text {od }}$ - income from operating activities, rubles;

D did - income from long-term investment activities, rubles;

$\mathrm{D}_{\text {kid }}$ - income from short-term investment activities, rubles;

$$
\begin{gathered}
\mathrm{ZT}_{\text {eosk }(\mathrm{p})}= \\
\frac{R_{o d}+R_{d i d}+R_{k i d}}{\left(D_{o d}+D_{d i d}+D_{k i d}\right)-\left(R_{o d}+D_{d i d}+D_{k i d}\right)},
\end{gathered}
$$

where ZT eosk (p) is the indirect integral static stability of the economy of organizations in terms of profit;

$\mathrm{R}_{\text {od }}$ - expenses from operating activities, rubles;

$\mathrm{R}_{\text {did }}$ - expenses from long-term investment activities, rubles;

$\mathrm{R}_{\text {kid }}$ - expenses from short-term investment activities, rubles;

$\mathrm{D}_{\text {od }}$ - income from operating activities, rubles;

$\mathrm{D}_{\text {did }}$ - income from long-term investment activities, rubles;

$\mathrm{D}_{\text {kid }}$ - income from short-term investment activities, rubles.
Both groups of indicators (in terms of income and profit) are qualitative, since they gharacterize the levels of implementation by organizations of their economic potential. Together with the quantitative indicators that form them, they affect the change in the result (formulas (5), (6)) and costs (formulas (7), (8)) related to the integral dynamic indicators of the stability of the economy of organizations:

$$
\begin{array}{r}
\mathrm{RT}_{\text {eodp (d) }}=d\left(\frac{D_{o d}+D_{\text {did }}+D_{\text {kid }}}{R_{\text {od }}+R_{\text {did }}+R_{\text {kid }}}\right) *\left[\left(R_{\text {od } 0}+\Delta R_{\text {od }}\right)+\right. \\
\left(R_{\text {did } 0}+\Delta R_{\text {did }}\right)+\left(R_{\text {kid } 0}+\right. \\
\left.\left.\Delta R_{\text {kid }}\right)\right],
\end{array}
$$

where RT eodp (d) is the direct integral dynamic stability of the economy of organizations in terms of income, rubles;

$d\left(\frac{D_{o d}+D_{d i d}+D_{k i d}}{R_{o d}+R_{d i d}+R_{k i d}}\right)$ - change in direct static stability of the economy of organizations in terms of income in a certain time interval;

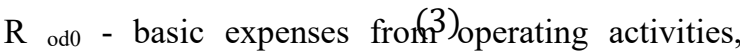
rubles;

$\Delta \mathrm{R}_{\text {od }}$ - change in expenses from operating activities in a certain time interval, rubles;

$\mathrm{R}$ did0 - basic expenses from long-term investment activities, rubles;

$\Delta \mathrm{R}$ did - change in expenses from long-term investment activities in a certain time interval, rubles;

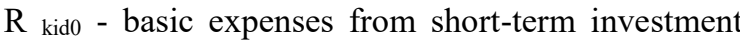
activities, rubles;

$\Delta \mathrm{P}$ kid - change in expenses from short-term investment activities in a certain time interval, rubles;

$$
\begin{array}{r}
\mathrm{RT}_{\text {eodp }(\mathrm{p})}=d\left(\frac{\left(D_{\text {od }}+D_{\text {did }}+D_{\text {kid }}\right)-\left(R_{\text {od }}+D_{\text {did }}+D_{\text {kid }}\right)}{R_{\text {od }}+R_{\text {did }}+R_{\text {kid }}}\right) * \\
{\left[\left(R_{\text {od } 0}+\Delta R_{\text {od }}\right)+\left(R_{\text {did } 0}+\Delta R_{\text {did }}\right)+\left(R_{\text {kid } 0}+\right.\right.} \\
\left.\left.\Delta R_{\text {kid }}\right)\right],
\end{array}
$$

where RT eodp (p) is the direct integral dynamic stability of the economy of organizations in terms of profit, rubles;

$d\left(\frac{\left(D_{o d}+D_{d i d}+D_{k i d}\right)-\left(R_{o d}+D_{d i d}+D_{k i d}\right)}{R_{o d}+R_{d i d}+R_{k i d}}\right)$ - change in direct static stability of the economy of organizations in terms of profit in a certain time interval;

P od0 - basic expenses from operating activities, rubles;

$\Delta \mathrm{P}_{\text {od }}$ - change in expenses from operating activities in a certain time interval, rubles;

$P$ dido - basic expenses from long-term investment activities, rubles;

$\Delta \mathrm{P}$ did - change in expenses from long-term investment activities in a certain time interval, rubles; 


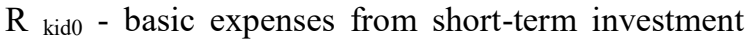
activities, rubles;

$\Delta \mathrm{P}$ kid - change in expenses from short-term investment activities in a certain time interval, rubles;

$$
\begin{array}{r}
3 \mathrm{~T}_{\text {эодп(д) }}=d\left(\frac{R_{o d}+R_{d i d}+R_{k i d}}{D_{\text {od }}+D_{\text {did }}+D_{\text {kid }}}\right) *\left[\left(D_{\text {od } 0}+\Delta D_{\text {od }}\right)+\right. \\
\left(D_{\text {did } 0}+\Delta D_{\text {did }}\right)+\left(D_{\text {kid } 0}+\right. \\
\left.\left.\Delta D_{\text {kid }}\right)\right],
\end{array}
$$

where ZT eodp (d) is the indirect integral dynamic stability of the economy of organizations in terms of income, rubles;

$d\left(\frac{R_{o d}+R_{d i d}+R_{k i d}}{D_{o d}+D_{d i d}+D_{k i d}}\right)$ - change in the indirect static stability of the economy of organizations in terms of income in a certain time interval;

$\mathrm{D}_{\mathrm{od} 0}$ - basic income from operating activities, rubles;

$\Delta \mathrm{D}$ od - change in income from operating activities in a certain time interval, rubles;

D dido - basic income from long-term investment activities, rubles;

$\Delta Д$ did - change in income from long-term investment activities in a certain time interval, rubles;

D kido - basic income from short-term investment activities, rubles;

$\Delta Д_{\text {kid }}$ - change in income from short-term investment activities in a certain time interval, rubles;

$$
\begin{array}{r}
\mathrm{ZT}_{\text {eodp (p) }}=d\left(\frac{R_{\text {od }}+R_{\text {did }}+R_{\text {kid }}}{\left(D_{\text {od }}+D_{\text {did }}+D_{\text {kid }}\right)-\left(R_{\text {did }}+D_{\text {did }}+D_{\text {kid }}\right)}\right) \\
{\left[\left(P_{\text {od } 0}+\Delta P_{\text {od }}\right)+\left(P_{\text {did } 0}+\Delta P_{\text {did }}\right)+\left(P_{\text {kid } 0}+\right.\right.} \\
\left.\left.\Delta P_{\text {kid }}\right)\right]
\end{array}
$$

where ZT eodp (p) is the indirect integral dynamic stability of the economy of organizations in terms of profit, rubles;

$$
d\left(\frac{R_{o d}+R_{d i d}+R_{k i d}}{\left(D_{\text {od }}+D_{\text {did }}+D_{\text {kid }}\right)-\left(R_{\text {did }}+D_{\text {did }}+D_{\text {kid }}\right)}\right) \text { - change in }
$$
the indirect static stability of the economy of organizations in terms of profit in a certain time interval;

$\mathrm{R}_{\text {od } 0}$ - basic profit from operating activities, rubles;

$\Delta \mathrm{R}_{\text {od }}$ - change in profit from operating activities in a certain time interval, rubles;

$\mathrm{R}$ did0 - basic profit from long-term investment activities, rubles;

$\Delta \mathrm{P}_{\text {did }}$ - change in profit from long-term investment activities in a certain time interval, rubles;

$\mathrm{R}$ kido - basic profit from short-term investment activities, rubles;

$\Delta \mathrm{R}_{\text {kid }}$ - change in profit from short-term investment activities in a certain time interval, rubles.
The author's statistical and dynamic indicators formed do not violate the principle of calculating efficiency and cost, and therefore do not contradict the traditional understanding of profitability, profitability, expenditure indicators of organizations. At the same time, they are collinear with the laws of the modern era, since they are adapted to the trends of diversification of business processes, which they try to follow in order to gain competitive advantages.

The semantic essence of static and dynamic indicators of the stability of the economy of organizations is given in tables 1,2 .

The semantic essence of the formed indicators disclosed in the tables testifies to the merits of the author's methods for assessing the sustainability of the economy of organizations:

1. Provide for the realities characteristic of the current economic conditions, based on a wide specialization of activities and a variety of cooperative ties with elements of a controlled (internal) and external (uncontrolled) environment.

2. Have a detailed structure of the calculated resulting static and dynamic indicators, designed to obtain accurate information about the degree of influence on them of each factor indicator and the priority of activities required to improve the values.

Based on these advantages, organizations will comprehensively analyze indicators of the stability of their economy for a specific time interval and a set of time intervals and determine both the overall implementation of the plan for them, and its implementation in each structural (operational, long-term and short-term investment) area.

\section{CONCLUSIONS}

The developed and proposed author's methods for calculating the indicators of the stability of the economy of organizations are consistent, because they do not at all contradict the classical scientific postulates that have relevance regardless of the historical period, and meet all market changes. Because objective economic rules are the same for all legal provisions, they will become a dependable applied toolset for firms engaged in every type of activity and adhering to any legal system.

The built methods' structure includes a comprehensive list of income and expense indicators required for objectively assessing the economic stability of organizations, obtaining reliable information about their general and specific parameters, and taking reasonable measures to balance profit between operating, long-term investment, and short-term investment activities, which is the study's applied significance.

Thus, by virtue of the identification of these methods, organizations, applying them in their activities, will be 
Table 1. Static indicators of economic sustainability of organizations

\begin{tabular}{|l|l|}
\hline \multicolumn{1}{|c|}{ Indicator } & \multicolumn{1}{|c|}{ Content } \\
\hline $\begin{array}{l}\text { Integral direct static stability of the economy of } \\
\text { organizations in terms of income }\end{array}$ & $\begin{array}{l}\text { The amount of operating, long-term investment and short- } \\
\text { term investment income of organizations per unit of the } \\
\text { amount of their expenses on similar business operations }\end{array}$ \\
\hline $\begin{array}{l}\text { Integral straight line static stability of the economy of } \\
\text { organizations in terms of profit }\end{array}$ & $\begin{array}{l}\text { The amount of operating, long-term investment and short- } \\
\text { term investment profits of organizations per unit of the } \\
\text { amount of their expenses on similar business operations }\end{array}$ \\
\hline $\begin{array}{l}\text { Integral indirect static stability of the economy of } \\
\text { organizations in terms of income }\end{array}$ & $\begin{array}{l}\text { The amount of operating, long-term investment and short- } \\
\text { term investment expenses of organizations per unit of the } \\
\text { amount of their income from similar business operations }\end{array}$ \\
\hline $\begin{array}{l}\text { Integral indirect static stability of the economy of } \\
\text { organizations in terms of profit }\end{array}$ & $\begin{array}{l}\text { The amount of operating, long-term investment and short- } \\
\text { term investment expenses of organizations per unit of the } \\
\text { amount of their profits from similar business operations }\end{array}$ \\
\hline
\end{tabular}

Table 2. Dynamic indicators of economic sustainability of organizations

\begin{tabular}{|l|l|}
\hline \multicolumn{1}{|c|}{ Indicator } & \multicolumn{1}{c|}{ Content } \\
\hline $\begin{array}{l}\text { Integral direct dynamic stability of the economy of } \\
\text { organizations in terms of income }\end{array}$ & $\begin{array}{l}\text { An increase (decrease) in the total income of organizations } \\
\text { due to a change (increase or decrease) in their total } \\
\text { profitability from a combination of operating, long-term } \\
\text { investment and short-term investment activities }\end{array}$ \\
\hline $\begin{array}{l}\text { Integral straight line dynamic stability of the economy of } \\
\text { organizations in terms of profit }\end{array}$ & $\begin{array}{l}\text { An increase (decrease) in the total profit of organizations due } \\
\text { to a change (increase or decrease) in their total profitability } \\
\text { from a combination of operating, long-term investment and } \\
\text { short-term investment activities }\end{array}$ \\
\hline $\begin{array}{l}\text { Integral indirect dynamic stability of the economy of of } \\
\text { organizations in terms of income }\end{array}$ & $\begin{array}{l}\text { Increase (decrease) in the total expenses of organizations } \\
\text { due to a change (increase or decrease) in their total expense } \\
\text { on income from a combination of operating, long-term } \\
\text { investment and short-term investment activities }\end{array}$ \\
\hline $\begin{array}{l}\text { Integral indirect dynamic stability of the economy of } \\
\text { organizations in terms of profit }\end{array}$ & $\begin{array}{l}\text { Increase (decrease) in the total expenses of organizations } \\
\text { due to a change (increase or decrease) in their total cost of } \\
\text { profit from a combination of operating, long-term } \\
\text { investment and short-term investment activities }\end{array}$ \\
\hline
\end{tabular}

able to proportionally distribute resources according to their types and optimize income, profit and expenses for them in static and dynamic periods and, thereby, provide themselves with the greatest financial benefit and a lasting long-term leadership.

\section{REFERENCES}

[1] E. G. Andrianova, S. A. Golovin, S. V. Zykov, S. A. Lesko, E. R. Chukalina, Review of modern models and methods for analyzing time series of dynamics of processes in social, economic and socio-technical systems. In: Russian technological journal, 8 (4(36)) (2020) pp. 7-45.

[2] B. G. Badmaev, The concept and principles of financial activities of organizations. In: Law and state: theory and practic, 11 (143) (2016) pp. 77-80.

[3] A. S. Bekasova, The economic potential of an enterprise as a factor in its competitiveness. In: Economics and efficiency of production organization, 33 (2021) pp. 95-97.

[4] N. S. Zinchik, Investment activity of organizations in the conditions of multivariance. In: Economy and entrepreneurship, 7 (96) (2018) pp. 666-669.

[5] Yu. N. Kulakova, A. B. Kulakov, Theoretical foundations of the formation of the strategy of the operating activity of an industrial enterprise. In: Economic analysis: theory and practice, 17(8) (2018) pp. 1449-1464.
[6] K. S. Levchuk, L. S. Abramova, Investment activity as a factor in increasing the efficiency of enterprises functioning. In: Economy vector, 1 (43) (2020) p. 85.

[7] D. Kh. Oleinik, Financial activities. In: Crimean academic bulletin, 4 (2017) pp. 234-237.

[8] M. A. Petrosyan, A. V. Khrapov, Assessment of the effectiveness of organizations: substantiation of legal and other indicators. In: Economy and society: modern development models, 16 (2017) pp. 122-134

[9] A. V. Samusenko, Directions to improve the efficiency of the enterprise. In: Economy vector, 1 (31) (2019), p. 68

[10] N. N. Sokolova, N. V. Zakharkina, Operating activities of the enterprise in modern conditions. In: Education and Science Without Borders: Basic and Applied Research, 6 (2020) pp. 54-60.

[11] A. N. Chesalin, S. Ya. Grodzensky, V. T. Pham, M. Yu. Nilov, A. N. Agafonov, Technology for assessing risks at the stages of the product life cycle using fuzzy logic. In: Russian technological journal, $8(6$ (38)) (2020) pp. 167-183.

[12] A. A. Yanyushkina, The efficiency of the enterprise. In: Agroforsite, 5 (17) (2018) p. 7. 